\title{
PELAKSANAAN KEWAJIBAN PEMERINTAH DAERAH SEBAGAI PEMBERI KERJA TERHADAP JAMINAN KESEHATAN PEGAWAI NEGERI SIPIL DIHUBUNGKAN DENGAN ASAS-ASAS UMUM PEMERINTAHAN YANG BAIK (Studi Kasus di Kabupaten Majalengka)
}

\author{
Bina Hermawan \\ bina.hermawan@bpjs-kesehatan.go.id \\ DOI : https://doi.org/10.29313/sh.v17i1.5362
}

\begin{abstract}
ABSTRAK
Program asuransi jaminan kesehatan bagi pegawai negeri sipil diatur dalam Undang-undang Sistem Jaminan Sosial Nasional yang ditindak lanjuti dengan lahirnya Peraturan Presiden No 111 Tahun 2013 Tentang Jaminan Kesehatan yang mewajibkan kepada peserta untuk membayarkan iuran sebesar 5\%, dengan ketentuan 3\% dibayar oleh pemberi kerja yaitu pemerintah Kabupaten Majalengka $2 \%$ dibayarkan oleh pekerja (PNS), akan tetapi dalam pelaksanaannya, aturan tersebut tidak dilaksanakan oleh pemerintah Kabupaten Majalengka yang seharusnya membayarkan iuran sebesar 3\% kepada BPJS sebagai penyelenggara kesehatan. Pemerintah Kabupaten Majalengka beralasan bahwa iuran jaminan kesehatan yang dibayar oleh pekerja (PNS) sebesar 2\% tersebut sudah cukup untuk mengcover program jaminan kesehatan bagi PNS. Sikap tindak pemerintah Kabupaten Majalengka tersebut bertentangan dengan Peraturan Presiden yang mewajibkan baik pemberi kerja maupun pekerja masing-masing dibebankan untuk membayar iuran jaminan kesehatan. Selain bertentangan dengan Peraturan Presiden sikap tindak tersebut juga bertentangan dengan asas-asas umum pemerintahan yang baik.
\end{abstract}

Kata kunci : Jaminan kesehatan Nasional, Pemerintah Daerah.

ABSTRACT

Health care insurance program for civil servants regulated in Act of the National Social Security System were followed up by the establishment of Presidential Decree No. 111 of 2013 About Health Insurance which require participants to pay a fee of 5\%, with the provision of $3 \%$ paid by the employer namely the district government Majalengka $2 \%$ paid by the employee (PNS), but in practice, these rules are not implemented by the District government is supposed to pay dues Majalengka 3\% to BPJS as health providers. Majalengka District Government argued that the health insurance contributions paid by workers (PNS) of $2 \%$ would be enough to cover the health insurance program for civil servants. The attitude of the Majalengka regency government acts contrary to the Presidential Decree which requires both employers and employees each pay dues charged to health insurance. In addition to an attitude contrary to the Presidential Regulation acts also contrary to the general principles of good governance. 
Keywords: National health insurance, Local Government.

\section{PENDAHULUAN}

\section{A. Latar Belakang Masalah}

Pada suatu negara hukum, ${ }^{1}$ seperti Indonesia maka sesuai dengan fungsi dan hakekatnya, hukum sangat besar perannya dalam mengatur setiap hubungan yang timbul, ${ }^{2}$ baik antara individu dengan individu ataupun antara individu dengan masyarakat di dalam berbagai bidang kehidupan termasuk kesehatan. Maka berbagai peraturan perundang-undangan yang mengatur tentang jamninan kesehatan bagi pegawai negeri sipil adalah sebagai norma yang harus ditaati demi tercapainya perlindungan jaminan kesehatan bagi abdi negara tersebut. ${ }^{3}$

Aturan hukum tentang penyelenggaraan kesehatan bagi pegawai negeri sipil telah diatur dalam undang-undang No 8 Tahun 1974 Tentang Pokok-pokok Kepegawaian yang telah diubah dengan undang-undang No 43 Tahun 1999 diperkuat dengan lahirnya Undang-undang No 40 tahun 2004 tentang Sistem Jaminan Sosial Nasional (SJSN) atau yang dikenal dengan sistem jaminan kesehatan nasional (JKN). Program ini ditentukan dengan sistem asuransi sosial bagi seluruh rakyat Indonesia baik peserta penerima bantuan iuran (PBI) maupun peserta bukan penerima bantuan iuran (PBPBI). Untuk melaksanakan program jaminan kesehatan nasional tersebut, maka pemerintah membentuk badan yang mengelola sistem tersebut dengan Undang-undang No 24 tahun 2011 tentang Badan Penyelenggara Jaminan Sosial (BPJS).

${ }^{1}$ Bagir Manan, Menyongsong Fajar Otonomi Daerah, Pusat Studi Hukum, Fakultas Hukum Universitas Islam, Jakarta, 2001, Hlm 173.

${ }^{2}$ Yudha Bhakti Ardiwisastra, Penafsiran dan Kontruksi Hukum, Alumni, Bandung, 2000, Hlm 7

${ }^{3}$ Veronica Komalawati, Peranan Informed Consent Dalam Transaksi Terapeutik, PT Citra Aditya Bhakti, Bandung, 2002, Hlm 65 
Peraturan perundang-undangan di atas ditindak lanjuti dengan adanya Peraturan Presiden No 111 Tahun 2013 Tentang Jaminan Kesehatan diantaranya dalam Pasal 16B yang mengatur jaminan asuransi kesehatan bagi pegawai negeri sipil yang mengatur bahwa:

(1). Iuran jaminan kesehatan bagi peserta pekerja penerima upah yang terdiri atas pegawai negeri sipil, anggota TNI, anggota Polri, pejabat negara, dan pegawai pemerintah non pegawai negeri sebesar 5\% (lima persen) dari gaji atau upah perbulan.

(2). Iuran sebagaimana dimaksud pada ayat (1) dibayar dengan ketentuan sebagai berikut:

a. 3\% (tiga persen) dibayar oleh pemberi kerja

b. $2 \%$ (dua persen) dibayar oleh peserta

(3). Kewajiban pemberi kerja dalam membayar iuran sebagaimana dimaksud dalam ayat (2) huruf (a) dilaksanaka oleh:

a. Pemerintah untuk iuran jaminan kesehatan bagi pegawai negeri sipil, anggota TNI, anggota Polri, pejabat negara, atau pegawai pemerintah non pegawai negeri pusat dan;

b. Pemerintah daerah untuk iuran jaminan kesehatan bagi pegawai negeri sipil daerah dan pegawai pemerintah non pegawai negeri daerah

Dalam tataran implementasi ketentuan Peraturan Presiden tersebut tidak dijalankan seperti di kabupaten Majalengka. Pemerintah daerah setempat mengungkapkan bahwa mereka tidak membayarkan APBD untuk iuran kesehatan pegawai negeri sipil di daerah tersebut, dengan alasan mereka memiliki otonomi daerah sendiri untuk membuat atau tidak membuat anggaran iuran asuransi kesehatan tersebut.

Tindakan pemerintah kabupaten Majalengka yang tidak membayarkan iuran untuk program asuransi kesehatan bagi pegawai negeri di lingkungan pemerintahannya adalah sebuah kewenangan yang dimilikinya namun kebijakan ini dirasa tidak memperhatikan kesehatan jiwa para pegawai negeri sipil yang mengabdi di wilayah pemerintahan tersebut. Padahal seharusnya pegawai negeri sipil di Kabupaten Majalengka, merupakan bagian dari abdi negara yang diberikan tugas di daerah untuk menjalankan roda pemerintahan yang harus diperhatikan kesehatannya.

Pemerintah daerah Majalengka, yang tidak membayarkan APBD untuk membayar iuran jaminan kesehatan bagi pegawai negeri sipil yang 
mengabdi di wilayahnya seharusnya tidak hanya mendasarkan kebijakan tersebut pada peraturan perundang-undangan yang memberikan kebebasan pemerintah daerah untuk mengatur atau tidak mengatur anggaran untuk iuran jaminan kesehatan bagi pagawai negeri sipil tetapi juga harus memperhatikan asas-asas umum pemerintahan yang baik sebagai pijakan untuk membentuk sebuah kebijakan yang berdampak pada kesejahteraan pegawai negeri sipil.

Adanya prinsip pelaksanaan pemerintahan daerah melalui desentralisasi. ${ }^{4}$ khususnya daerah Majalengka membuat program asuransi kesehatan melalui iuran dari pemerintah untuk pegawai negeri sipil tidak berjalan seperti yang diharapkan. Hal ini tentunya perlu menjadi perhatian pemerintah khsusunya pemerintah daerah Majalengka karena dapat mengganggu kinerja dari pegawai negeri di daerah tersebut. Seharusnya kesehatan bagi pegawai negeri sipil dijamin oleh peraturan perundangundangan yang berlaku yang harus dijalankan dan dijaga demi terselenggaranya roda pemerintahan daerah yang baik.

\section{B. Identifikasi Masalah}

1. Bagaimana tanggung jawab pemerintah daerah kabupaten dalam rangka penyelenggaraan jaminan kesehatan nasional khususnya bagi pegawai negeri sipil?

2. Bagaimana pelaksanaan pemberian jaminan kesehatan bagi Pegawai Negeri Sipil (PNS) di Kabupaten Majalengka berdasarkan Peraturan Presiden No 111 Tahun 2013 Tentang Jaminan Kesehatan dihubungkan dengan asas-asas umum pemerintahan yang baik?

\footnotetext{
${ }^{4}$ Sunaryati Hartono, Politik Hukum Menuju Satu Sistem Hukum Nasional, Alumni, Bandung, 1991,
} Hlm 22 


\section{Metode Penelitian}

Metode penelitian dalam penulisan ini menggunakan pendekatan yuridis normatif karena menggunakan data sekunder di bidang hukum seperti Undang-undang No 23 Tahun 2014 Tentang Pemerintahan Daerah Peraturan Presiden No 111 Tahun 2013 Tentang Jaminan Kesehatan Undang-undang 40 Tahun 2004 Tentang Sistem Jaminan Sosial Nasional, Undang-undang No 24 Tahun 2011 Tentang Badan Penyelenggara Jaminan Kesehatan (BPJS), KUHP, buku, jurnal dan makalah-makalah. Teknik pengumpulan data menggunakan studi kepustakaan, sedangkan teknik analisis data menerapkan metode kualitatif.

\section{PEMBAHASAN}

\section{A. Tanggung Jawab Pemerintah Daerah Kabupaten Dalam Rangka Penyelenggaraan Jaminan Kesehatan Nasional Khususnya Bagi Pegawai Negeri Sipil}

Pemerintah daerah bertanggung jawab atas upaya kesehatan, penyelenggaraan upaya kesehatan harus memperhatikan fungsi sosial, nilai dan norma agama, sosial, budaya, moral dan etika profesi. Pemerintah dan pemerintah daerah bertanggung jawab meningkatkan dan mengembangkan upaya kesehatan. Upaya kesehatan ini sekurang-kurangnya memenuhi kebutuhan kesehatan dasar masyarakat. Peningkatan dan pengembangan upaya kesehatan dilakukan berdasarkan pengkajian dan penelitian. Sedangkan ketentuan mengenai peningkatan dan pengembangan upaya kesehatan dilaksanakan melalui kerjasama antar pemerintah dan antar lintas sektor. $^{5}$

\footnotetext{
${ }^{5}$ Soekidjo Notoatmodjo, Etika dan Hukum Kesehatan, Rineka Cipta, Jakarta, 2010, Hlm 2
} 
Seperti halnya di sektor-sektor lain, pemerintah adalah sebagai penanggung jawab semua pembangunan. Oleh sebab itu, di sektor kesehatan pemerintah juga bertanggung jawab merencanakan, mengatur, menyelenggarakan, membina dan mengawasi penyelenggaraan upaya kesehatan yang merata dan terjangkau oleh masyarakat. Hal ini diatur dalam Pasal 14 Undang-undang No 36 Tahun 2009 Tentang Kesehatan yang menegaskan bahwa:

"Pemerintah bertanggung jawab merencanakan, mengatur, menyelenggarakan, membina dan mengawasi pengelenggaraan upaya kesehatan yang merata dan terjangkau oleh masyarakat"

Tanggung jawab pemerintah sebagaimana dimaksud di atas, meliputi pemerintah pusat dan pemerintah daerah. Wujud tanggung jawab pemerintah pusat dan daerah dalam pelaksanaan jaminan kesehatan dilaksanakan melalui sistem jaminan kesehatan nasional. Sesuai Pasal 20 ayat (1) Undang-undang No 36 Tahun 2009 Tentang Kesehatan yang menegaskan bahwa:

"Pemerintah bertanggung jawab atas pelaksanaan jaminan kesehatan masyarakat melalui sistem jaminan sosial nasional bagi upaya kesehatan perorangan"

Kepesertaan jaminan kesehatan nasional sebagaimana dimaksud dalam ketentuan Pasal 20 di atas meliputi pekerja penerima upah, pekerja bukan penerima upah dan bukan pekerja. Pegawai negeri sipil di lingkungan pemerintah daerah dalam kepesertaan tersebut termasuk golongan peserta pekerja penerima upah yang berhak menerima jaminan pemeliharaan kesehatan nasional yang diselenggarakan oleh pemerintah daerah bagi seluruh rakyat Indonesia.

Tanggung jawab pemerintah dalam hal pengaturan mengenai jaminan kesehatan nasional telah dilaksanakan dengan lahirnya beberapa peraturan seperti Undang-undang 40 Tahun 2004 Tentang Sistem Jaminan Sosial Nasional, Undang-undang No 24 Tahun 2011 Tentang Badan 
Penyelenggara Jaminan Kesehatan (BPJS), Peraturan Presiden No 111 Tahun 2013 Tentang Jaminan Kesehatan dan sebagainya.

Tanggung jawab pemerintah dalam penyelenggaraan upaya kesehatan telah diupayakan melalui sistem jaminan kesehatan nasional (SJSN) bagi seluruh rakyat Indonesia, yang dalam pelaksanaannya telah didelegasikan kepada Badan Penyelenggara Jaminan Sosial (BPJS). Badan penyelenggara mencatat setiap peserta yang terdaftar sebagai penerima jaminan sosial termasuk di dalamnya pegawai negeri sipil.

\section{B. Pelaksanaan Pemberian Jaminan Kesehatan Bagi Pegawai Negeri Sipil di Kabupaten Majalengka Berdasarkan Peraturan Presiden No 111 Tahun 2013 Tentang Jaminan Kesehatan Dihubungkan Dengan Asas- asas Umum Pemerintahan yang Baik}

Jaminan pemeliharaan kesehatan dimaksudkan untuk meningkatkan produktivitas pekerja, sehingga dapat melaksanakan tugas sebaik-baiknya dan merupakan upaya kesehatan di bidang penyembuhan (kuratif). Upaya penyembuhan diperlukan setiap orang, maka sudah selayaknya diupayakan penanggulangan kemampuan masyarakat melalui program jaminan sosial tenaga kerja. Jaminan pemeliharaan kesehatan bagi perusahaan yakni bagi perusahaan dapat memiliki tenaga kerja yang sehat, dapat konsentrasi dalam bekerja sehingga lebih produktif. ${ }^{6}$

Kewajiban pemerintah daerah Kabupaten Majalengka untuk membiayai iuran jaminan kesehatan bagi pegawai negeri sipil di lingkungan pemerintah daerah diatur dalam Peraturan Presiden No 12 Tahun 2013 sebagaimana telah diubah dengan Peraturan Presiden No 111 Tahun 2013 lahirnya Peraturan Presiden ini merupakan perintah dari ketentuan Pasal 13

\footnotetext{
${ }^{6}$ Asri Wijayanti, Hukum Ketenagakerjaan Pasca Reformasi, Sinar Grafika, Jakarta, 2013, Hlm 140
} 
Undang-undang No 40 Tahun 2004 Tentang Sistem Jaminan Sosial Nasional menyebutkan bahwa:

(1). Pemberi kerja secara bertahap wajib mendaftarkan dirinya dan pekerjanya sebagai peserta kepada Badan Penyelenggara Jaminan Sosial, sesuai dengan program jaminan sosial yang diikuti.

(2). Penahapan sebagaimana dimaksud pada ayat (1) diatur lebih lanjut dalam Peraturan Presiden.

Ketentuan di atas ditindak lanjuti oleh Presiden dengan mengeluarkan Peraturan Presiden No 12 Tahun 2013 sebagaimana telah diubah dengan Peraturan Presiden No 111 Tahun 2013 Tentang Jaminan Kesehatan yang mewajibkan pemerintah daerah termasuk pemerintah daerah Kabupaten Majalengka untuk membayar iuran jaminan kesehatan pegawai negeri sipil. Iuran untuk jaminan kesehatan pegawai negeri sipil ini dibebankan pada anggaran pendapatan dan belanja daerah Kabupaten Majalengka (APBD).

Norma dari Peraturan Presiden No 111 Tahun 2013 Tentang Jaminan Kesehatan diantaranya dalam Pasal 16B yang mengatur mengenai besaran iuran jaminan kesehatan bagi pegawai negeri sipil menegaskan bahwa:

(1). Iuran jaminan kesehatan bagi peserta pekerja penerima upah yang terdiri atas pegawai negeri sipil, anggota TNI, anggota Polri, pejabat negara, dan pegawai pemerintah non pegawai negeri sebesar 5\% (lima persen) dari gaji atau upah perbulan.

(2). Iuran sebagaimana dimaksud pada ayat (1) dibayar dengan ketentuan sebagai berikut:

a. 3\% (tiga persen) dibayar oleh pemberi kerja

b. $2 \%$ (dua persen) dibayar oleh peserta

(3). Kewajiban pemberi kerja dalam membayar iuran sebagaimana dimaksud dalam ayat (2) huruf (a) dilaksanaka oleh:

a. Pemerintah untuk iuran jaminan kesehatan bagi pegawai negeri sipil, anggota TNI, anggota Polri, pejabat negara, atau pegawai pemerintah non pegawai negeri pusat dan;

b. Pemerintah daerah untuk iuran jaminan kesehatan bagi pegawai negeri sipil daerah dan pegawai pemerintah non pegawai negeri daerah 
Berdasarkan ketentuan di atas, maka pemerintah daerah Kabupaten Majalengka berkewajiban untuk mengalokasikan/menganggarkan sebagian dana dari APBD Kabupaten Majalengka untuk iuran jaminan kesehatan bagi pegawai negeri sipil di lingkungan pemerintahan Kabupaten Majalengka dengan membayarkannya kepada Badan Penyelenggara Jaminan Sosial (BPJS).

Akan tetapi dalam pelaksanaannya ketentuan Peraturan Presiden mengenai kewajiban pemerintah daerah untuk membayar iuran jaminan kesehatan bagi pegawai negeri sipil di atas tidak dilaksanakan oleh Pemerintah Kabupaten Majalengka khususnya dalam hal ini Bupati Majalengka. Bupati berpendapat bahwa iuran jaminan kesehatan yang telah dibayarkan oleh peserta (PNS) sebesar 2\% di lingkungan pemerintah Kabupaten Majalengka itu telah mencukupi untuk mengcover upaya jaminan pemeliharaan kesehatan, sehingga iuran jaminan kesehatan yang dibebankan kepada pemerintah daerah sebesar 3\% untuk jaminan kesehatan pegawai negeri sipil sampai saat ini tidak dibayarkan kepada Badan Penyelenggara Jaminan Sosia (BPJS).

Terdapat perbedaan pendapat antara Bupati dengan pihak legislatif atau DPRD Kabupaten Majalengka, pihak DPRD menyetujui anggaran sebesar 2,500.000.000 untuk dianggarkan guna membiayai iuran jaminan kesehatan PNS di lingkungan Pemerintah Kabupaten Majalengka. Akan tetapi sampai saat ini anggaran yang telah disetujui tersebut belum juga disetorkan kepada Badan Penyelenggara Jaminan Sosial. Hal ini membuat hubungan antara legislatif dan eksekutif di Kabupaten Majalengka menjadi kurang harmonis dan persoalan ini terus berlarut-larut sampai sekarang dan membuat upaya penyelenggara jaminan kesehatan bagi pegawai negeri sipil di lingkungan Kabupaten Majalengka tidak berjalan sebagaimana mestinya.

Ketentuan Peraturan Presiden yang memberi kewajiban kepada pemerintah daerah untuk membayar iuran jaminan kesehatan pegawai negeri sipil sebesar 3\% merupakan peraturan yang menjadi tindak lanjut dari perintah Undang-undang No 40 Tahun 2004 Tentang Sistem Jaminan 
Sosial Nasional yang mewajibkan pemberi kerja (Pemkab Majalengka) untuk memungut pembiayaan jaminan kesehatan dari pekerja dan menambahkan iuran yang menjadi kewajibannya.

Bila ditinjau dari susunan peraturan perundang-undangan sebagaimana diatur dalam Pasal 7 Undang-undang No 12 Tahun 2011 Tentang Pembentukan Peraturan Perundang-undangan, susunan peraturan perundang-undangan terdiri dari:

1. Undang-undang Dasar 1945

2. Ketetapan MPR

3. Undang-undang/Perppu

4. Peraturan Pemerintah

5. Peraturan Presiden

6. Peraturan Daerah Provinsi

7. Provinsi Daerah Kabupaten/kota

Berdasarkan ketentuan di atas Peraturan Presiden menjadi salah satu peraturan perundang-undangan yang tertulis dan memiliki kekuatan mengikat secara umum. Sebagai pemegang kekuasaan pemerintahan, presiden harus memiliki kekuasaan untuk membuat suatu kebijakan atau suatu peraturan perundang-undangan yang ia anggap sebagai pelaksana dari undang-undang. Kedudukan Peraturan Presiden adalah subordinat terhadap peraturan pemerintah, karena itu undang-undang tidak dapat memerintahkan peraturan pelaksananya langsung pada peraturan presiden, namun terlebih dahulu mendelegasikan pada peraturan pemerintah, tetapi dalam undang-undang juga seringkali langsung mendelegasikan kepada pada peraturan presiden.

Perintah dalam hal ini dapat diartikan secara tegas maupun implisit (impliedly delegated legislation). Dengan kata lain, meskipun tidak ada perintah tegas dari undang-undang dan peraturan pemerintah, Presiden sebagai pemegang kekuasan pemerintahan berdasarkan Pasal 4 ayat (1) UUD 1945 memiliki kekuasaan inherent untuk membentuk peraturan presiden dalam rangka menjalankan kekuasaan pemerintah itu. 
Akan tetapi peraturan presiden ini dibuat dalam rangka mengimplementasikan ketentuan-ketentuan peraturan perundang-undangan yang lebih tinggi atau yang mendelegasikannya. Norma peraturan presiden tidak dapat bersifat mandiri atau membentuk hukum sendiri, terpisah atau bertentangan dengan peraturan perundang-undangan yang mendelegasikan. Apabila norma peraturan presiden itu bersifat mandiri, membentuk hukum sendiri yang terpisah atau bertentangan dengan peraturan perundangundangan yang mendelegasikan maka peraturan presiden ini dapat dinyatakan tidak sah oleh Mahkamah Agung atau batal demi hukum. Oleh karena itu dalam diktum perancang peraturan presiden harus merujuk undang-undang dan peraturan pemerintah yang menjadi dasar pembentukannya.

Bila dilihat dari latar belakang pembentukan Peraturan Presiden No 111 Tentang Jaminan Kesehatan, peraturan presiden tersebut dibentuk berdasarkan perintah dari Undang-undang No 40 Tahun 2004 Tentang Sistem Jaminan Sosial Nasional dan Undang-undang No 24 Tahun 2011 Tentang Badan Penyelenggara Jaminan Sosial. Oleh karena itu, peraturan presiden yang mengatur kewajiban pemerintah daerah Kabupaten Majalengka untuk membayar iuran sebesar 3\% untuk jaminan kesehatan bagi pegawai negeri sipil memiliki kekuatan mengikat secara penuh kepada pemerintah kabupaten Majalengka dan isi norma peraturan presiden No 111 Tahun 2013 itu sudah sesuai dan tidak bertentangan dengan undang-undang yang mendelegasikan.

Kekuatan mengikat peraturan presiden tentang Jaminan Kesehatan wajib diaplikasikan oleh pemerintah daerah Kabupaten Majalengka untuk membayarkan iuran sebesar 3\% kepada badan penyelenggara kesehatan sebagai upaya mewujudkan jaminan kesehatan guna menghormati jasa para pegawai negeri sipil yang telah mengorbankan tenaga dan pikirannya untuk kepentingan pemerintah daerah Kabupaten Majalengka.

Apabila pemerintah Kabupaten Majalengka dalam hal ini Bupati tidak melaksanakan Peraturan Presiden No 111 No Tahun 2013, maka 
Dewan Perwakilan Rakyat Daerah (DPRD) Kabupaten Majalengka dapat menggunakan fungsi kontrolnya atau menggunakan salah satu haknya untuk menanyakan motivasi dari sikap tindak Bupati Majalengka, mengingat iuran jaminan kesehatan tersebut berkaitan dengan kepentingan pemeliharaan kesehatan seluruh pegawai negeri sipil di lingkungan pemerintah Kabupaten Majalengka.

Bila ditinjau dari asas-asas umum pemerintahan yang baik yang berlaku dalam sistem ketatanegaraan di Indonesia, tindakan pemerintah Kabupaten Majalengka yang tidak membayar iuran jaminan kesehatan bagi pegawai negeri sipil sesungguhnya sikap tersebut bertentangan dengan asas keadilan dan kewajaran. Asas ini mengehndaki agar setiap tindakan badan atau pejabat administrasi negara dalam hal ini Pemkab Majalengka selalu memperhatikan aspek keadilan dan kewajaran. Asas keadilan menuntut tindakan secara proporsional, sesuai, seimbang dan selaras dengan hak setiap orang khususnya hak pegawai negeri sipil terutama hak atas pemeliharaan kesehatan yang optimal. Oleh karena itu, setiap pejabat pemerintah dalam melakukan tindakannya harus selalu memperhatikan aspek keadilan ini. Sementara itu, asas kewajaran menekankan agar setiap aktivitas pemerintah atau administrasi negara memperhatikan nilai-nilai yang berlaku di tengah masyarakat baik itu berkaitan dengan moral, adat istiadat, maupun nilai-nilai lainnya.

Sikap Pemkab Majalengka yang tidak melaksanakan kewajiban atau tidak membayarkan iuran jaminan kesehatan selain tidak sesuai dengan asas keadilan, juga tidak sejalan dengan asas kepercayaan dan pengharapan yang wajar, karena iuran jaminan kesehatan sebesar 5\% dan 3\% diantaranya akan dibayar oleh Pemkab selaku pemberi kerja yang telah diatur dalam peraturan perundang-undangan ternyata dalam realisasinya tidak dilaksanakan oleh pemberi kerja. Tindakan Pemkab tersebut tidak dapat memenuhi harapan yang wajar bagi para pegawai negeri sipil di Kabupaten Majalengka untuk memperoleh pembayaran iuran yang maksimal sebagaimana telah diatur secara eksplisit oleh undang-undang. Menurut M 
Hadjon asas-asas umum pemerintahan yang baik harus dipandang sebagai norma-norma hukum tidak tertulis yang senantiasa harus ditaati oleh pemerintah, Asas-asas pemerintahan yang baik merupakan sebagian dari kejiwaan manusia yang merupakan cita-cita yang hendak diraihnya. Dengan demikian, apabila asas-asas umum pemerintahan yang baik dimaknakan sebagai asas atau sendi hukum, asas-asas umum pemerintahan yang baik dapat dikatakan sebagai asas hukum yang bahannya digali dan ditemukan dari unsur susila, didasarkan pada moral sebagai hukum riil, bertalian erat dengan etika, kesopanan dan kepatutan berdasarkan norma yang berlaku. ${ }^{7}$

Bila diteliti lebih lanjut Peraturan Presiden yang mengatur mengenai kewajiban pemerintah Kabupaten Majalengka untuk membayar iuran merupakan tindak lanjut dari undang-undang jaminan sosial nasional yang menganut beberapa prinsip yang bertujuan untuk memberikan jaminan kesehatan bagi para pegawai negeri sipil di Kabupaten Majalengka sebagai abdi negara untuk mendapatkan hak-hak mereka sesuai peraturan perundangan yang telah menetapkan hak tersebut. Mengingat pada awal kemunculannya asas-asas umum pemerintahan yang baik dimaksudkan sebagai sarana perlindungan hukum (rechtsbescherming) dan bahkan dijadikan sebagai instrumen untuk peningkatan perlindungan hukum bagi warga negara terhadap tindakan pemerintah. Oleh karena itu, bila dikaji lebih jauh sikap tindak pemerintah Kabupaten Majalengka yang tidak melaksanakan kewajiban membayar iuran jaminan kesehatan pegawai negeri sipil yang telah nyata-nyata diatur dalam peraturan perundangundangan merupakan sikap tindak yang tidak selaras dengan asas-asas pemerintahan yang baik yang menghendaki adanya perlindungan terhadap warga negara (PNS) terhadap tindakan pemerintah.

Norma yang mengatur kewajiban pemerintah daerah untuk membayar iuran jaminan kesehatan yaitu Pasal 16B Perpres No 111 Tahun 2013 merupakan norma hukum yang sudah cukup jelas dan tidak perlu

\footnotetext{
${ }^{7}$ Ridwan HR, Hukum Administrasi Negara, Rajawali Press, Jakarta, 2006, Hlm 250
} 
ditafsirkan oleh pemerintah daerah Majalengka dan tidak ada alasan bagi pemerintah daerah Kabupaten Majalengka untuk tidak membayar iuran sebesar 3\% kepada badan penyelenggara jaminan kesehatan karena kondisi keuangan daerah pemerintah Kabupaten Majalengka juga memungkinkan untuk menganggarkan iuran guna jaminan kesehatan para pegawai negeri sipil di Kabupaten Majalengka.

\section{PENUTUP}

\section{A. Simpulan}

1. Pemerintah daerah Kabupaten memiliki tanggung jawab atas penyelenggaraan upaya kesehatan untuk memenuhi kebutuhan dasar masyarakat khususnya pegawai negeri sipil sebagai abdi negara. Tanggung jawab pemerintah daerah Kabupaten atas pelaksanaan jaminan kesehatan ditegaskan dalam Pasal 12 ayat (1) Undang-undang No 23 Tahun 2014 Tentang Pemerintahan Daerah dan Pasal 20 ayat (1) Undang-undang No 36 Tahun 2009 Tentang Kesehatan serta Pasal 16B Peraturan Presiden No 111 Tahun 2013 Tentang Jaminan Kesehatan.

2. Dasar hukum perlindungan/jaminan kesehatan bagi pegawai negeri sipil (PNS) sudah jelas dan tegas baik dalam Undang-undang maupun Peraturan Presiden. Akan tetapi Pemerintah daerah Kabupaten Majalengka sebagai pemberi kerja tidak melaksanakan atau tidak bersedia membayarkan iuran jaminan kesehatan. Hal ini dapat dikualifikasikan bahwa pemerintah daerah Kabupaten Majalengka tidak menaati aturan tentang iuran jaminan kesehatan (tidak bertanggung jawab) dan juga bertentangan dengan asas keadilan dan kewajaran dan asas pengharapan yang wajar sebagai bagian dari asas-asas pemerintahan yang baik.

\section{B. Saran}

1. Sebagai pejabat yang memegang kekuasaan eksekutif dan memiliki kewenangan untuk mengelola keuangan daerah, Bupati Kabupaten 
Majalengka harus mengalokasikan/menganggarkan sebagian dana dari APBD Kabupaten Majalengka untuk segera disetorkan kepada Badan Penyelenggara Jaminan Kesehatan (BPJS) guna mewujudkan sistem jaminan kesehatan yang optimal bagi pegawai negeri sipil di lingkungan pemerintah Kabupaten Majalengka.

2. Bilamana pemerintah Kabupaten Majalengka tetap tidak menaati Peraturan Presiden No 111 Tahun 2013 Tentang Jaminan Kesehatan untuk membayarkan iuran sebesar 3\% kepada badan penyelenggara jaminan kesehatan, maka pihak legislatif (DPRD) Kabupaten Majalengka dapat menggunakan salah satu fungsinya seperti fungsi controlling untuk mengawasi pelaksanaan jaminan kesehatan bagi pegawai negeri sipil di lingkungan pemerintah Kabupaten Majalengka. Mengingat dalam Peraturan Presiden tidak terdapat norma mengenai sanksi yang dapat dijatuhkan kepada eksekutif yang tidak menaatinya. 


\section{DAFTAR PUSTAKA}

\section{A. Buku}

Asri Wijayanti, Hukum Ketenagakerjaan Pasca Reformasi, Sinar Grafika, Jakarta, 2013.

Bagir Manan, Menyongsong Fajar Otonomi Daerah, Pusat Studi Hukum, Fakultas Hukum Universitas Islam, Jakarta, 2001.

Ridwan HR, Hukum Administrasi Negara, Rajawali Press, Jakarta, 2006.

Soekidjo Notoatmodjo, Etika dan Hukum Kesehatan, Rineka Cipta, Jakarta, 2010 .

Sunaryati Hartono, Politik Hukum Menuju Satu Sistem Hukum Nasional, Alumni, Bandung, 1991.

Veronica Komalawati, Peranan Informed Consent Dalam Transaksi Terapeutik, PT Citra Aditya Bhakti, Bandung, 2002.

Yudha Bhakti Ardiwisastra, Penafsiran dan Kontruksi Hukum, Alumni, Bandung, 2000.

\section{B. Peraturan Perundang-undangan}

Undang-undang Dasar 1945

Undang-undang No 43 Tahun 1999 tentang Pokok-pokok Kepegawaian

Undang-undang No 40 Tahun 2004 tentang Sistem Jaminan Sosial Nasional

Undang-undang No 24 Tahun 2011 tentang Badan Penyelenggara Jaminan Sosial.

Undang-undang No 23 Tahun 2014 tentang Pemerintahan Daerah

Peraturan Pemerintah No 28 Tahun 2003 tentang Subsidi dan Iuran Asuransi Kesehatan bagi Pegawai Negeri Sipil dan Penerima Pensiun

Peraturan Presiden No 111 Tahun 2013 tentang Jaminan Kesehatan 